\title{
Законы души в прозах Николая Воронова
}

\author{
Зденька Матыушова \\ (Ческе-Будеёвице, Чешская Республика)
}

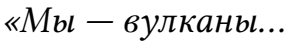

Как ни странно, в нас зарождаются

Волны морские, и птицы, и злаки,

и самоцветы».

(Н. Воронов)
\end{abstract}

Николай Павлович Воронов (2о ноября 1926г., Троицк - 18 июня 2014 г., Москва) - русский писатель, поэт и публицист, жизнь и творчество которого связаны с родным Уралом, где прошли его детство и юность, и с городом Магнитогорск, где он работал на металлургическом комбинате. Не окончив Магнитогорский педагогический институт, он в 1948 году переехал в Москву. Его исконно уральскую душу уже с молодости привлекала литературная деятельность. Он поступил в Литературный институт им. Горького и пробовал писать стихотворения и прозу. В 1952 году окончил институт и вернулся в Магнитогорск профессиональным писателем. Сборник его первых рассказов под названием «Весенней порой» вышел из печати в 1956 году и Воронова тогда и приняли в Союз писателей России. С 2004 года он стал главным редактором журнала «Вестник Российской литературы» (Москва-Магнитогорск) и с 2005 года членом редакционного совета книжной серии «Литература Магнитки. Избранное». Под его руководством сформировались многие молодые писатели того времени, например А. Турусов, Н. Курочкин, В. Машковцев и некоторые другие.

Николай Воронов неоднократно удостаивался литературных премий, званий и наград - медаль Академии Российской словесности «Ревнителю просвещения» (1999), Академик Академии литературы (2001), Золотая Есенинская 
медаль (2007), Памятная медаль имени А.П. Чехова (2009), Премия имени Д. Н. Мамина-Сибиряка (2011) и др.

К последующим замечательным произведениям Николая Воронова принадлежат прежде всего романы, повести и сборники рассказов «Кассирша» (1955), «Бунт женщины» (1958), «Нейтральные люди» (1958), «Ожидание» (1959), «Просто Иван» (1960), «Человек-эхо» (1962), «Мальчик, полюбивиий слона» (1963), «Бег в ночи» (1965), «Не первая любовь» (1968), «Женское счастье» (1969), «Смятение» (1970), «Юность в Железнодольске» (1972), «Закон души» (1973), «Макушка лета» (1976), «Непокой на асфальте» (1976), «Голубиная охота» (1977), «Котёл. Лягушонок на асфальте» (1982), «Похитители солнца» (1986), «Крик о помощи» (1986), роман-антиутопия «САМ» (1988), «Побег в Индию» (2001), «Теплье монеты» (2006), циклы стихотворений «Перемены» (2005), «Цунами» (2005), «Моя крылатая родня» (2006), «Вечное и хрупкое» (2006), воспоминание-эссе о его откровенном мнении и критическом отношении к событиям в стране, в обществе и в литературе с названием «Истина о самом себе, о Переделкине, Магнитке, Калуге, Оптиной Пустыни, Москве и о тех, кто был оклеветан» (2010-2011) и другие.

Имя Николая Воронова стоит всегда рядом с именами русских писателей, какими были Федор Абрамов, Борис Можаев, Виктор Астафьев, Евгений Носов, Василий Белов, Владимир Солоухин, Сергей Залыгин, Валентин Распутин и прочие.

«О Николае Воронове можно сказать словами русского писателя Н. Лескова, которьй не раз говорил, что ему не было нужды изучать жизнь народа, поскольку он сам жил этой жизнью, поскольку он сам - частица своего народа» [VUKOLOV 1983, 3].

В прозах Николая Воронова описывается трудная жизнь современного города и его жителей, прежде всего простых рабочих. Как энциклопедист и мастер тонкой детали писатель восхищается красотой родной уральской природы и постепенно складывается повествование об особом укладе быта его земляков - уральцев, о их ярких и крепких характерах.

«По окраинам Железнодольска холмы, покрытые травой... пруд становится зеркально-серым... Во всем этом приятность... Тут просто очумляющая красота. Другая планета!.. А по падям - ирисы: желтые лепестки, красные узоры. А на обдувах - неветреные ветрениць: только вокруг берез, и тех берез, что на отшибе и нетесно растут...

Чашечки белье, пятилепестковые, схожие с иветами шиповника, но гораздо изящней.. бель, как березовая кора, - чисто, тепло. Вдобавок нежные до прозрачности.

А запах такой тонко-тонкий, что аромат ландыша перед ними груб...» [VORONOV 1983b, 37]. 
Перед глазами отрывается панорама пейзажа - это великое начало, когда природа и край расцветают весной и летом, как особые и своеобразные существа, полные сил и гармонии, или отдыхают в ночной свежести и прохладе осеннего и зимнего умиротворения. Именно такие образы одновременно символизируют и несомненное единство земли с космосом.

«Прошло лето, и опять на нашем огороде. Осенняя тепльнь. Безоблачно. Серебристый блеск паутины... Ть выворачиваешь из сухой земли густо-розовую скороспелку, жадно вдыхаешь вкусную, пахнущую солнцем, коноплей и польнью поднятую лопатой пыль: то мурлыкаешь, сам того не замечая, радостную песню, то свищешь счастливо, как жаворонок» [VORONOV 1983a, 350].

Каждый крупный художник пользуется своим писательским видением жизни, которое выражает его общественные и творческие позиции. Николай Воронов испытывает и ощущает себя в исторически восходящем течении современности - и с такой высоты перед ним открываются новые творческие кругозоры и горизонты.

Он постоянно пытался понять космос и поэтому его представления о земной жизни как бы переносились на всю вселенную, так как и там происходит постоянная поляризация и разветвление сил, столкновение добра и зла, непрерывный конфликт добрых божеств, духов и существ со злыми божествами, духами и существами. Николай Воронов сумел постичь неведомую живым тайну перехода из состояния временного в состояние вечности. Поэтому и вороновские размышления наполнены представлениями о единстве человека и вселенной, о звездном небесном существовании и земной природе, о ощущении мирового всеединства и синтеза конечного и бесконечного. «...он воспринимал дома, дороги, поля и лес вокруг, как живые и роднье существа, следил за перелетом птии, и, слушая его, я вдруг замечал, что воздух вокруг нас вдруг начинал звенеть. Небо становилось близким, а звезды появились на небосклоне для бесед с ним, вселенная была тут, где он» [GUSEJNOV 2016, 21].

В автобиографическом романе «Юность в Железнодольске» (1972) Воронов рассказывает о своем детстве и о желании почти каждого человека вернуться в свою молодость.

«До переезда в Железнодольск я вижу себя почти только летом. Веснь, зимы, осени прошли сквозь мою память... С Железнодольска я вижу себя в осенях, а позже и в веснах» [VORONOV 1983a, 183].

Одновременно эта прямо хрупкая носталгия по детству совмещается с предвидением будущего и с раздумьями о жизни следующих генераций. Узловую часть романа писатель посвятил детям военных лет и вообще людям этого трудного времени. Вороновские герои - это дети своего народа, своей эпохи, своего времени, которые не могли прожить свои детские радости 
и мечты. Но несмотря ни на что, они стремятся рядом со взрослыми охранять, защищать и оборонять своих друзей и всю свою страну. В связи с тем об этом всем пишет в своем дневнике и главный герой Костя Кукурузин. И поэтому так сильно, убедительно и актуально звучат финальные слова романа:

«Костя Кукурузин был убит двадиати пяти лет. Сейчас ему было бы сорок семь. В месяц его гибели мне было восемнадцать, а теперь - за сорок. Время от времени я листаю Костины записи. Они воскрещзают в моей памяти образ этого человека, лучше которого не знает мое детство.

Я боюсь бестревожности. Я нуждаюсь в его беспокойстве. Оно спасительней любого оптимизма, потому что исходило из истинной правды, а также из опасностей, которые остались» [VORONOV 1983a, 524].

Николай Воронов стремится художественно воплотить свои взгляды на философские проблемы земного бытия и человеческого существования. Лирические вороновские герои много говорят и философствуют о человеке, о земле, о природе, о смысле жизни - Что земля без людей? Никому не нужный шар. Шар, лишенный ума... И суть смысла всего этого скрыта в слове родина - это земля человеческого рода. И это понятие недаром ассоцируется и связывается со словами мать и природа. Наконец-то отсюда исходит и чувствование счастья и желание писателя сохранить лицо природы.

«Основным ощущением моей довоенной жизни было ощущение счастья. Но больше всего я чувствовал себя счастливым не тогда, когда мать работала в хлебном магазине... а тогда, когда мать сидела в стеклянной, просторной кабине главного поста и двигала рукоятки главного контроллера» [VORONOV 1983a, 305].

«Ожидание весен... Надежды на продолжение жизни. Приток воды. Приток сини. Приток воли... Мечты сбудутся: будет ликование, радуга над всей землей и счастье - надежное, вечное...

И настуило это время. И пало оно именно на весну. И не было раньше никогда долгожданней, счастливей весны. И уже не было и после.

Чего на земле печалиться? Явилась весна!» [VORONOV 1983a, 499].

На протяжении всего своего творческого жизнеописания Николай Воронов уделяет постоянное внимание взаимоотношениям разных поколений и наиболее часто его привлекает психология подростка с его жизненными проблемными вопросами, к решению которых он пока неподготовлен и часто делает поспешные и необдуманные выводы. Автор изображает душевный свет подростков и то, как они ищут понимания, совета и опоры среды окружающих их взрослых. Именно такие душевные самочувствия и физические состояния выражает само название новеллы «Смятение» (1970).

«Я здесь у вас, как в сказке, вышла на развилку трех дорог. На двух ждет горе, на одной - счастье. Какая дорога счастливая - нет указателя. Каждое поколение 
в общем-то похоже. До нашего поколения люди думали, что они всегда будут жить, а мы думаем, что на нас может закончиться жизнь» [VORONOV 1983b, 30-31].

«Тогда я еще не знал, как непредусмотрительно счастье, как оно заблуждается, полагаясь на свою всесильность и непрерывность. В счастье ли единственный смыл жизни? А может, высший смысл в том, чтобы не бояться несчастия и решаться на такие перемены, к которым путь на грани катастрофы, а то и в катастрофу?» [VORONOV 1983b, 95].

Прозу Николая Воронова отличает с самого начала многообразие характеров, реальных деталей и наблюдений. В его повестях есть тоже эмоциональная полнота миропонимания и мировосприятия, намеренное и сознательное стремление и усилие автора к обширному диапазону ощущений и переживаний его героев. Воронов гармонизирует творения природы с созданиями человеческих рук и чутко реагирует на нечувствительность людей в отношении к жизни вокруг них. Он ищет ответ на вопрос, как во все более совершенном цивилизованном мире не нарушить, а сохранить всечеловеческие нравственные ценности.

«Если мы погибнем, кто заменит нас? Никто. Нас не заменить в том смысле, что мы единичны, неповторимы. Те, кто останется, оправдают ли они нашу гибель верностью нашей борьбе, значительным трудом, духовной красотой, возвышением совести? Мертвым все равно, однако, покудова мын живы и заботимся о будущем, каким его вообразили и выносили, нам хочется, чтоб наш ранний уход претворился во все самое прекрасное, чего жаждут трудолюбивые люди мира» [VORONOV 1983a, 524].

Писатель создал удивительный и многоцветный мир огромных человеческих страстей, желаний и благородных помыслов, в которых утверждается не только его уверенность в себя, но, прежде всего, и незатухающая вера в человечность.

Автор, как и его герои, стремится угадать в поведении людей то отношение, которое «различает не посты и возрасты, а человека, его благородство, ум, доброжелательнось, душевную опрятность» [VORONOV 1983b, 19-20]. Его герои взяты из реальной действительности, и в них, как в каждом человеке, много разного - злого и доброго, хорошего и плохого, смешного и печального, притягательного и отталкивающего, положительного и отрицательного.

Во всех прозах Николая Воронова проявляется его большой писательский талант, мастерство, человеческая память, доброта, любовь к людям, правда, защита совести и самоуверенная моральная отвага. Он не боялся четко высказать свое суровое, жесткое и строгое отношение ко лжи, злу, насилию, обиде, ненависти, несправедливости и ко всему, что калечит человека. 
«Николай Воронов как писатель и человек никогда не отличался нормативной покладистостью, суетливой уступчивостью слова и характера. Он ярко социален в слове, резко тревожен в поведении... Очернительство, клевету на герочческие будни рабочего класса приписывали ему неудержимо-ретивые критики» [SOROKIN 2011]. Все это приносило ему немало затруднений и он даже вынужден был покинуть Калугу, куда он переселился из Магнитогорска. Но он уехал не от простых рабочих людей, а от странного, глупого, мстительного бюрократизма.

Без всякого пафоса можно сказать, что замечательные произведения Николая Воронова не только улавливают и отражают мир, но и переформируют и пересоздают его. В своих прозах он хвалил и воспевал человека, его личность и красоту человеческой жизни. Как всякое истинное искусство, проза этого русского писателя обнаруживает и открывает, а тем самым помогает осознать целый мир человеческих чувствований, духовных и моральных потрясений, страстных желаний и нравственных поисков человека. Николай Воронов был писатель, который излагал и объяснял мир, чувствовал его и мечтал о том, чтобы он стал гораздо лучше.

\section{Библиография:}

GUSEJNOV, Č. (2016): Venok pamjati Nikolaju Voronovu. Obščepisatel'skaja Literaturnaja gazeta, № 6, 2016, s. 21.

SOROKIN, V. (2011): Slovo o Nikolaje Voronove. In: Vest' news. <http://www.vest-news. $\mathrm{ru} /$ article/20938>. [online]. [cit. 28. 8. 2018].

VORONOV, N. (1983a): Junost'v Železnodol'ske. In: VORONOV, N.: Izbrannyje proizvedenija v 2-ch t. Moskva, s. 154-526.

VORONOV, N. (1983b): Smjatenije. In: VORONOV, N.: Izbrannyje proizvedenija v 2-ch t. Moskva, s. 28-175.

VUKOLOV, L. (1983): Vstupitel'naja stat'ja. In: VORONOV, N.: Izbrannyje proizvedenija v 2-ch t. Moskva, s. 3-12.

\section{Summary}

\section{The Laws of the Soul in Nikolay Voronov's Proses}

Nikolay Pavlovich Voronov (1926-2014) counts among excellent and the most outstanding Russian writers. His work ranks with the classical writers of Russian literature such were Fyodor Abramov, Boris Mozhayev, Sergey Zalygin, Vladimir Solouchin, Ivan Akulov, Victor Astafyev, Valentin Rasputin, Evgeniy Nosov, Vasyliy 
Belov and others. Nikolay Voronov was a novelist, poet, publicist and the author of more than thirty books. All his life is connected with the town of Magnitogorsk in Chelyabin region. His recalls of his childhood there became later the basis for his autobiographic novel Youth in Zeleznodolsk (1972). Apart from others, Voronov also wrote the following proses In Spring Time (1956), Boiler (1982), Peak summer (1976), Flight to India (2001). In all his books, he describes with subtle psychological vertones noticeable and convincing characters of people living in the Urals and depicts the picturesque countryside of the unique Ural region.

\section{Об авторе}

Zdeňka Matyušová, University of South Bohemia in České Budějovice, Faculty of Education, Department of Slavic Languages and Literatures, Department of Russian Language and Literature

České Budějovice, Czech Republic, matyus@pf.jcu.cz 
